\title{
Lumen
}

Selected Proceedings from the Canadian Society for Eighteenth-Century Studies

\section{Frances Burney and the Marketplace}

\section{Lorna Clark}

Volume 38, 2019

URI : https://id.erudit.org/iderudit/1059271ar

DOI : https://doi.org/10.7202/1059271ar

Aller au sommaire du numéro

Éditeur(s)

Canadian Society for Eighteenth-Century Studies / Société canadienne d'étude du dix-huitième siècle

ISSN

1209-3696 (imprimé)

1927-8284 (numérique)

Découvrir la revue

Citer cet article

Clark, L. (2019). Frances Burney and the Marketplace. Lumen, 38, 31-52.

https://doi.org/10.7202/1059271ar d'utilisation que vous pouvez consulter en ligne.

https://apropos.erudit.org/fr/usagers/politique-dutilisation/ 


\title{
Frances Burney and the Marketplace
}

\author{
LORna Clark \\ Carleton University
}

Frances Burney's writing, as has oft been noted, addresses issues of money, gender and especially class. ${ }^{1}$ Of the latter, one has only to think of scenes that are quintessentially Burney: those in which the heroine fears to be perceived as a woman of a lower class than she is (Evelina on the arms of the prostitutes, encountering Lord Orville); is embarrassed by her association with those more vulgar than she (when with the Branghtons at the opera); or in which she aspires to belong to a class higher than her own (the aristocratic circle at Mrs. Beaumont's). As Margaret Anne Doody has written, Burney's "fiction is at its heart political," and the "clash of cultures and groups and personal ideologies is a large source of her humour."2 A classic scene in a Burney novel or play is one in which characters from different classes jostle with each other to comic effect: for instance, when the penny-pinching Mr.

1. Well-known feminist critiques of Burney are found in essays by Susan Staves, Judith Lowder Newton, and Rose Marie Cutting, and two monographs by Patricia Meyer Spacks, The Female Imagination (New York: Knopf, 1975) and Imagining a Self (Cambridge, MA: Harvard University Press, 1976), both of which include Burney. A helpful outline of the three stages of feminist criticism in relation to Burney is given in Janice Thaddeus, Frances Burney: A Literary Life (Houndsmill, Basingstoke: Palgrave Macmillan, 2000). A recent essay on the subject is Vivien Jones, "Burney and Gender," in The Cambridge Companion to Frances Burney, ed. Peter Sabor (Cambridge: Cambridge University Press, 2007), 111-29. However, Elles Smallegoor makes the case that "existing studies of Frances Burney's fiction are too gendercentred and need to be complemented by a class-centred reading of her novels," in "Novel Upstarts: Frances Burney and the Lower Middle Class." PhD diss., University of Aberdeen, 2010), o.

2. Margaret Anne Doody, "Burney and Politics," Cambridge Companion, ed. Sabor, 93-110, 96, 99 . 
Briggs and the haughty Mr. Delvile meet in Cecilia, or when the nouveaux-riche Watts family encounters Sir Marmaduke and Lady Wilhelmina in A Busy Day. These social sensitivities can ultimately be traced to money: in Burney's novels, financial anxieties are often at the core, which we see represented in Camilla's cascading debts, Cecilia's loss of her fortune, or the Wanderer's frustrating attempts to make a living. Critics have addressed the topic of finance in Burney's novels, noting its relation to a "rapidly expanding industrialist consumer society" in which shopping and gambling became fashionable, or to developments in retail culture. ${ }^{3}$

These concerns, which mark her fiction, are also reflected in Burney's journals. The family's place in London society was an equivocal one; the image presented in Burney's Memoirs of her father Charles Burney is that of a self-made man who managed to rise from humble origins by virtue of his musical, literary and social abilities; he himself was well aware of his status as an outsider who had won his way (as he wrote), "I still remain a drudge amid the smiles of Wealth \& Power." ${ }^{\prime}$ Burney's letters evince the same sensitivities; she constantly reassures herself and her correspondents of her social acceptance into a higher class than her own. She even boasts to her father when she is at court of the aristocratic friends she is making, evidently expecting his approval. 5 The equivocal social position of the Burneys had an impact on her love life as well: Burney's lack of wealth and status may

3. Andrea Henderson, "Commerce and Masochistic Desire in the 1790s: Frances Burney's Camilla," Eighteenth-Century Studies 31.1 (Fall 1997): 69-86, 80. Monographs on monetary aspects of the period that consider Burney in their discussion include: Edward Copeland, Women Writing about Money: Women's Fiction in England, 1790-1820 (Cambridge: Cambridge University Press, 1995); James Thompson, Models of Value: Eighteenth-Century Political Economy and the Novel (Durham: Duke University Press, 1996); and Deidre Lynch, The Economy of Character: Novels, Market Culture, and the Business of Inner Meaning (Chicago: University of Chicago Press, 1998). An influential article on the subject is D. Grant Campbell, "Fashionable Suicide: Conspicuous Consumption and the Collapse of Credit in Frances Burney's Cecilia," Studies in Eighteenth-Century Culture 20 (1991): $131-45$.

4. The Letters of Dr Charles Burney, vol. 1, 1751-84, ed. Alvaro Ribeiro (Oxford: Clarendon Press, 1991), 318.

5. The Court Journals and Letters of Frances Burney, vol. 3, ed. Lorna J. Clark (Oxford: Clarendon Press, 2014), 288-89. 
have discouraged her apparent suitor, the Revd George Cambridge; 6 it probably affected even more her relationship with Stephen Digby, a fellow-courtier with an aristocratic pedigree, who seemed drawn to Burney but who, in the end, married a woman of his own class. ${ }^{7}$ Class consciousness played a large part in Burney's deep unhappiness in the Queen's household; faced with a rigid protocol in which everyone's place was strictly determined by birth and position, Burney (for all her wit, intelligence and literary accomplishments) could not escape awareness of her lowly status. Suffering the indignity of being summoned by "a Bell!," she served a Queen who was notably adept in making subtle social distinctions evident simply by the way she addressed people. 'Burney's sensitivities about her status extended far beyond court; more than a decade after the rupture with Hester Thrale, Burney still complained about the indelicate way Mrs. Thrale had once pressed gifts upon her, which had made her feel inferior. ${ }^{10}$

Into these ongoing discussions, a new element has been introduced: a discovery about Burney's beloved mother, Esther Sleepe (who died when Burney was ten), whose implications I shall be exploring in this paper, first more broadly in reference to Burney's novels, and then more specifically in Burney's journals. Building on previous research, Amy Louise Erickson has recently discovered that not only did Esther Sleepe's mother, Frances Sleepe, own a fan shop, with which Esther and her sisters Martha and Mary helped, but also that Esther herself ran her own shop (as did Martha and Mary), at least for a while. A set of business trade cards in the British Museum shows that the daughters operated from three locations along Cheapside, a main commercial thoroughfare in London: Martha and Esther both operated under the

6. For a discussion of the relationship, see Stewart J. Cooke, "Sweet Cecilia and Brown George: Editing Volume 5 of Burney's Early Journals and Letters, 1782-83," The Burney Journal 3 (2000): 28-47.

7. For more on this relationship, see Lorna J. Clark, "Epistolarity in Frances Burney," The Age of Johnson 20 (2010): 193-222.

8. In the first three days of her employment in the Queen's household, Burney expressed her dismay at her "mode of Call; a Bell!-it seemed so mortifying a mark of servitude, I always felt myself blush, though alone, with conscious shame at my own strange degradation." The Court Journals and Letters of Frances Burney, vol. 1, ed. Peter Sabor (Oxford: Clarendon Press, 2011), $3^{8 .}$

9. Olwen Hedley, Queen Charlotte (London: John Murray, 1975), 34.

10. The Additional Journals and Letters of Frances Burney, vol. 2, ed. Peter Sabor (Oxford: Oxford University Press, 2018), 49. 
sign of "the Golden Fan and Seven Stars," "but Martha's shop was located at the west end of Cheapside "next Door to the Black Swan, the North Side of St Paul's Churchyard,' while Esther's was at the east end "opposite the Old Jewry in the Poultry."'ll This property was bought by the family in 1746 when Esther was 21 ; she sold fans and jewellery there between 1747 and 1749, then moved further east to Fenchurch Street in 1749, until she left some two years later for King's Lynn, after which there is no further evidence of her trading at all. ${ }^{12}$ Burney's grandmother meanwhile continued in business until at least 1753, possibly until 1767 , according to Erickson; ${ }^{13}$ she died before 11 December 1773 , on which day her will was proved. ${ }^{14}$ Although the total length of time that Esther Sleepe ran her own business may not have been long (perhaps five years at most), the discovery is nevertheless suggestive and fraught with implications.

The news should not come as a complete surprise, as it builds on information that was previously known but which has been largely overlooked or mistaken by Burney scholars. In the few fragments of his own Memoirs allowed by Madame d'Arblay to survive, Charles Burney wrote, after referring to his wife's mother and grandfather, the words, " $<$ kept $>$ a fan shop in Cheapside" which the editors took to refer to the grandfather, adding a "who" in their transcript to make this referent clear, which appears now to have been a misinterpretation. ${ }^{15}$ Citing the

11. Amy Louise Erickson, "Esther Sleepe, Fan-Maker, and Her Family," Eighteenth Century Life 42.2 (April 2017): 15-37, 18.

12. Erickson speculates that Charles Burney's annual visits to London in the 1750 s may have involved buying stock, and even that Esther may have accompanied him ("Esther Sleepe," 25). However, Charles's own explanation of the purpose of his visits was "to keep up his acquaintance, and prevent professional rust" in preparation for his intended return to the capital. Charles Burney, Memoirs of Dr. Charles Burney 1726-1729, ed. Slava Klima, Garry Bowers, and Kerry S. Grant (Lincoln: University of Nebraska Press, 1988), 132.

13. Erickson deduces that Frances Sleepe was still in the fan business in 1753 from the evidence of her husband taking an apprentice "who was clearly destined to serve his wife." The date 1767 comes from the Return of Papists records in which Frances Sleepe describes herself as a "fan-maker" ("Esther Sleepe," 29).

14. Will of Frances Teresia Sleepe, Fan Maker of Saint Michael Le Querne, City of London PROB 11/993/180, cited in Erickson, "Esther Sleepe," 37 n. 52.

15. The angled brackets around the word " $<$ kept $>$ " indicate a conjectural reading; the square brackets around "[who]" indicate the word is an editorial insertion. In the original manuscript, then, the passage would have read, "the daughter of a M. Dubois, $<1$ illegible word $>$ a Fan Shop in Cheapside" which might be interpreted 
same passage from the fragmentary memoirs, Joyce Hemlow had noted in 1972 that Esther Sleepe's parents ran a fan shop (which dealt in music as well), ${ }^{16}$ and later added information (from the Church Rate Books for St Mary Cole) that Esther Sleepe had paid rent and the Scavenger's Rate on a property in the Poultry between 1747 and 1749, the latter of which was taken over at Easter 1749 by Charles Burney. (The timing is significant, as it was just before their first child was born in May and their own marriage in June. $)^{17}$ Looking at these same parish records, Erickson moves up the date that Charles Burney paid the rates on the shop to Christmas $1748 .^{18}$ Both scholars assume that he must have been living there at the time, although it is hard to reconcile that suggestion with Charles Burney's own statement that he was "entirely domesticated with $\mathrm{M}^{\mathrm{r}}$ Greville, and accountable to him for my time," after September 1748 when Fulke Greville bought out his indentures with Thomas Arne. ${ }^{19}$ It seems more likely that, in paying the rates, Charles Burney was simply shouldering responsibility for Esther Sleepe, who was already pregnant with his child but whom he felt he could not marry without the permission of his employer. ${ }^{20}$

While the fan shop in Cheapside and the connection of the family to trade was mentioned in some of the biographies of Frances Burney, ${ }^{21}$ the news that Esther Sleepe herself ran a fan shop was not, although it had in fact been discovered by C. J. F. Comyn who lodged a pedigree of the Burney family at the College of Arms in 1995 and shared some of her findings in print a few years later. These findings included a

to mean that Mrs. Sleepe (and not her father) was the shopkeeper (Memoirs of Dr. Charles Burney, xxxvi, 83). When this passage is quoted without the brackets, as in Claire Harman, Fanny Burney: A Biography (New York: HarperCollins, 2000), 8n, it gives a misleading impression. In her lengthy note, Harman outlines the confusion about Esther Sleepe's parentage. Erickson also cites this passage in "Esther Sleepe" (16).

16. The Journals and Letters of Fanny Burney, vol. 1, Joyce Hemlow (Oxford: Clarendon Press, 1972), 68 n. 7.

17. A daughter, Esther, had been born on 24 May, and was baptized a month later, on 25 June 1749, the same day as the wedding (Memoirs of Dr. Charles Burney, xxxvi, 83, 84 nn. 1, 2). See The Journals and Letters of Fanny Burney, vol. 12, Joyce Hemlow (Oxford: Clarendon Press, 1984), 762-3, n. 1.

18. Erickson, "Esther Sleepe," 21.

19. Memoirs of Dr. Charles Burney, 81 .

2o. Ibid., 84 .

21. Kate Chisholm, Fanny Burney: Her Life, 1752-1840 (London: Chatto \& Windus, 1998), 8; Harman, 8-10. 
correction of the name and identity of Esther's father (Richard, not James, Sleepe) and the fact that, "Esther Sleepe was definitely in Trade-she and her sister Martha had become Free of both the City and of the Musicians' Company by Patrimony in August of 1747 and Esther had kept a fan and music shop in the Poultry until her marriage in 1749." Comyn also notes that Esther "had to relinquish her Freedoms on marriage but at almost the same time as she was giving up her own, her husband because a Freeman by Redemption." 22 Although this information was available, it had not been built on by scholars until Erickson's full exploration, presented with additional archival evidence.

The discovery of Esther Sleepe's fan shop, when we pause to consider the implications, has an impact on our view of the Burney family, and especially Charles Burney himself. The image of Charles Burney as a self-made man who started from "humble" beginnings, and rose solely through his own "diligence, talents, or conduct," a view outlined in his own handwritten "manuscript memoir," 23 and elaborated in the Memoirs written by his daughter, requires some adjustment. The notion that he was the sole earner, struggling heroically to support his family, a claim made by several scholars (as Erickson points out), ${ }^{24}$ must be adjusted to the fact that his wife may also have contributed to the family income, at least in the beginning. Although he wrote that "there was no fortune on either side" at the time of their marriage, ${ }^{25}$ Charles was prone to exaggerate his own self-sufficiency, as he did when he claimed not to have touched "a penny" of his second wife's fortune, which he said was almost all lost before he married her, a claim that was patently untrue. ${ }^{26}$

22. C.J.F. Comyn, "Recording the Burney Pedigree at the College of Arms," Burney Letter 5.2 (Fall 1999): 5-6, 5. Comyn has corrected the pedigree of the Burney family and discussed some of her findings. She also corrects the erroneous identification of Esther's father as James (repeated in several places) to Richard.

23. Frances Burney, The Memoirs of Doctor Burney, by his daughter, Madame d'Arblay (London: Edward Moxon, 1832), vol. 1, x.

24. Erickson, "Esther Sleepe," 21.

25. Memoirs of Dr. Charles Burney, 84.

26. The phrase occurred in a letter of Charles Burney's (which has since disappeared), quoted in Journals and Letters, vol. 12, 780, L. 1430. The controversy is outlined in the footnotes to that letter, written by Frances (Burney) d'Arblay in response to Elizabeth Allen's son, Stephen. Further discussion of Charles Burney's exaggerated claims of disinterestedness, and the documents that contradict them are found in Appendix A (ibid.), 181-2; Percy A. Scholes, The Great Dr. Burney: His Life, 
On the other hand, it is also possible to make too much of the circumstance. Erickson's claims for a "highly successful business" that "earned the major part of household income," making Esther "the primary earner in the household," and for the Sleepe women providing "multiple models of elegant, professional, self-confident prosperity" are rather large assertions that would seem to be unproven. ${ }^{27}$ The will of grandmother Sleepe mentions debts that must be paid, disposes of less than $£_{2} \mathrm{O}$ in cash, and then carefully divides up her apparel, specifying which of her silk garments should go to which daughter; to her eleven grandchildren, she leaves a guinea each. By contrast, in his will, Charles Burney had sufficient means to divvy up about $£ 7000$ and, as a comparable token of affection to his twenty-one grandchildren, left them each £100. ${ }^{28}$ Moreover, two of Esther Sleepe’s siblings (including one who ran a fan shop), or their families, relied on handouts from the Burneys for years. Esther's brother James, an "impecunious, illiterate, but sweet-natured man-of-all-work," was a dependent in various Burney households until his death in 1794, shuffled around from one to another for weeks at a time; he lived off the money he received from his nieces and nephews. To help support him, Frances Burney regularly earmarked a portion of her salary as his pension. ${ }^{29}$ His own children apparently could not support him in his old age, and not surprisingly, since they too were recipients of Burney largesse: his two daughters both figure on Frances Burney's list of charitable donations until 1828, and were also kindly assured they might ask for more in times of need. ${ }^{30}$ Besides this family of cousins, the children of Esther's

His Travels, His Works, His Family and His Friends (London: Oxford University Press, 1948), vol. 2, 306-8; Stewart J. Cooke, “The 'Fortune' of Elizabeth Allen Burney," Notes and Queries 39.1 (1992): 61; and Lorna J. Clark, "The Fortune of Elizabeth Allen Burney Reconsidered," Notes and Queries 42.4 (1995): 462-67.

27. Erickson, "Esther Sleepe," 21-22, 30.

28. Will of Frances Teresia Sleepe, n. 13 above. Charles Burney's will is printed in Scholes, The Great Dr. Burney, vol. 2, 261-75. Although his will was written 34 years later than hers (and proved 41 years later), the rate of inflation was not high during that period so would not be a significant factor in the difference between the amounts.

29. Joyce Hemlow, The History of Fanny Burney (Oxford: Clarendon Press, 1958), 4, 216; Journals and Letters, ed. Hemlow, vol. 1, 68 n. 7, 106; The Court Journals and Letters of Frances Burney, vol. 5, ed. Geoffrey Sill (Oxford: Clarendon Press, 2016), 100 and n. 239, 126, 250 n. 630, 312.

30. Journals and Letters, vol. 1, ed. Hemlow, $68 \mathrm{n}$. 7; The Journals and Letters of Fanny Burney, vol. 9, ed. Joyce Hemlow (Oxford: Clarendon Press, 1982), 205, 329; 
sister's Mary, who had also run a fan shop, needed continual support. Mary's son, James Sansom, lived as a dependent, first in Charles Burney Jr's household where he served as a "man of all work," and then (after Charles's death) in that of James Burney; Sansom also received regular donations from his female cousins, Frances and Charlotte. ${ }^{31}$ There does not seem to be evidence of much "prosperity in the Sleepe family" in all of this. ${ }^{32}$

Be that as it may, my purpose here is less to deal with biographical facts than to draw out some of the implications of these discoveries on Burney's writing. Once possessed of this key, the reader is alerted and sensitized to certain patterns in both her public and private writing which thereby acquire new resonance. For instance, her intense idealization of her grandmother Sleepe as an "angel upon earth" is quite striking; ${ }^{33}$ Frances Sleepe probably fulfilled an important maternal role to Burney after the early death of her mother in 1762 . Part of what drew Burney to the elderly Mary Delany was the resemblance she bore in her "Countenance" to Burney's "sweet Grand mother Sleepe," in that "benevolence, softness, piety, \& gentleness are all resident in her Face." ${ }^{4}$ And Mary Delany, Burney notes in another place (quoting Burke approvingly), was "a pattern of a perfect fine lady, a real fine lady, of other Days." ${ }^{35}$ The equivalence of genteel qualities that is implied in this comparison is surprising, given that one woman ran a fan shop in Cheapside and the other was friend to the royal family. The difference was not unimportant to Burney who never, to my knowledge, allowed any piece of writing to survive in which she mentioned her

The Journals and Letters of Fanny Burney, vol. 11, ed. Joyce Hemlow (Oxford: Clarendon Press, 1984), xxi, 43 n. 27, 405 n. 8.

31. The Journals and Letters of Fanny Burney, vol. 3, ed. Joyce Hemlow, (Oxford: Clarendon Press, 1973), 175; Journals and Letters, vol. 6, ed. Joyce Hemlow, (Oxford: Clarendon Press, 1975), 473; Journals and Letters, vol. 9, ed. Hemow, 205; Journals and Letters, vol. 11, ed. Hemlow, xxi, 43 n. 16, 405 n. 8; The Early Journals and Letters of Fanny Burney, vol. 1, ed. Lars Troide, (Oxford: Oxford University Press; Montreal and Kingston, McGill-Queen's University Press, 1988), 171, n. 81.

32. Erickson, "Esther Sleepe," 30. While it might be possible that individual families would fall on hard times, it seems significant that the Sleepes seem to have turned to the Burneys for relief, rather than to each other.

33. The Memoirs of Doctor Burney, by his Daughter, vol. 1, 79 .

34. The Early Journals and Letters of Fanny Burney, vol. 5, ed. Lars Troide and Stewart J. Cooke (Oxford: Oxford University Press; Montreal and Kingston, McGillQueen's University Press, 2012), 283-284, emphasis in orginal.

35. Journals and Letters, vol. 1, ed. Hemlow, 198, emphasis in orginal. 
mother's or grandmother's involvement with trade, although she did rebuke her nephew Richard Allen Burney for his even greater sensitivity when he requested that she avoid even mentioning the Sleepe family in her Memoirs of her father. ${ }^{36}$

It is curious that while in the private writing, the angelic grandmother appears in the guise of a 'fine lady' of gentle birth, yet in Burney's first novel, Evelina (1778), a different sort of figure appearsthe nightmarish figure of Madame Duval, tawdry and vulgar, rising suddenly out of the past, persecuting the heroine with her attentions and insisting on being paid respect as her grandmother. Connected to France, though not actually French (like her grandmother Sleepe who, Burney believed, was the daughter of a Huguenot refugee), ${ }^{37}$ Mme. Duval is condemned by association with her humble occupation and status, that of barmaid. Her outrageous behaviour is one of the main sources of humour in the novel, and the moment of her humiliation (when she is left beaten and tied in a ditch) seems meant to be cathartic, a fitting chastisement for her unwomanly aggression and troublesome persecution of the heroine. This juxtaposition or duality, the saintly grandmother of the private writing and the wicked grandmother of the fiction (shamed for her foreignness and low social status) who "with her continual wrangling and ill-breeding" made Evelina "blush" to belong to her, ${ }^{38}$ offers a stark contrast that is heightened by a new awareness of Burney's background (the fan shop looming in the shadows). The class sensitivities which so often characterize Burney's novels

36. Richard Allen Burney felt that the revelations of his humble forebears, the Sleepe family, would be an embarrassment. Having married well, he was anxious to establish a respectable lineage, and had applied successfully for armorial bearings for the Burney family (which were granted, on 8 August 1807). The Pedigree that was entered inaccurately identifies Esther Sleepe's father as "James Sleepe, gentleman," and claims a lineage from "an extinct West Country family named Burney!" (Comyn, 5; Journals and Letters, vol. 11, ed. Joyce Hemlow, xxii-xxiii; vol. 12, 760-64 and nn.

37. In the Memoirs she wrote of her father, Frances Burney writes that her grandmother was "originally of French extraction, from a family of the name of Dubois," that her father was a Huguenot, but that she, "from some unknown cause-probably of maternal education-had been brought up a Roman Catholic" (Memoirs of Doctor Burney, by his Daughter, vol. 1, 79-80). Erickson finds no evidence of Huguenot extraction, pushes back the date at which the name was anglicized to the late seventeenth century, and argues convincingly that the family was always Catholic ("Esther Sleepe," 26-7).

38. Frances Burney, Evelina or the History of a Young Lady's Entrance into the World, ed. Edward A. Bloom (Oxford: Oxford University Press, 1982), 58. 
and plays do tend to focus on family relations as the source of embarrassment; in Evelina, these relations include not only a grandmother but also a set of vulgar cousins connected with trade (the Branghtons), who, from their shop in Snow Hill, try to milk Evelina's fashionable acquaintances for profit. It is hard to avoid the notion that, in some way, Burney's first novel exorcises the ghost of the shame of her own humble forebears.

Having this key to knowledge is like having a secret map to Burney's writings, something akin to the literal map of Evelina's London, the geographical world of the novel (recently plotted by Britanny Miller who has created an interactive map that she shares on the web). ${ }^{39}$ The map shows that many scenes in the novel take place in the West End, for instance, in Queen Anne Street, the house where Evelina stays with the Mirvans, or at the theatres and ridotto she visits with them; others take place further east, for instance, at the hosier's in High Holborn where she stays with Mme. Duval, or Snow Hill, the Branghtons' house in the commercial area of London. The class divide in the novel is thus represented geographically by the distance between the two areas. It is in the east, within the boundaries of the City, that the three fan shops on Cheapside are located..$^{40}$ The point is that the haunts of the cits, whose portrayal by Burney has long been praised as so convincing (like the "Holbourn beau" that was Johnson's favourite), ${ }^{41}$ are not far removed from the commercial interests of the Sleepe family. The Cinderellalike quality of Evelina ("just think, Polly! Miss has danced with a Lord!”) 42 acquires a deeper resonance with this knowledge.

Then there is the striking scene that opens The Witlings (1779), which (as Doody remarks) bursts upon us with the "freshness of

39. Brittany Miller, "Mapping Evelina: Discovering the Places in Frances Burney's Evelina," updated September 15, 2016, http://univredlands.maps.arcgis.com/ apps/MapJournal/index.html?appid= $=5$ of $4 \mathrm{~d}_{4} \mathrm{~d} 8 \mathrm{aad}_{1} 4 \mathrm{~d} 2 \mathrm{obfa}_{3} \mathrm{Od} 4 \mathrm{caefored}_{1}$

40. The sites of the three fan shops are conveniently plotted on a map of London as an illustration to Erickson's article on "Esther Sleepe" (20).

41. The Early Journals and Letters of Fanny Burney, vol. 3, ed. Lars Troide and Stewart J. Cooke (Oxford: Oxford University Press; Montreal and Kingston, McGillQueen's University Press, 1994), 89.

42. The Cinderella-like quality of Evelina has been discussed in an article by Kenneth Graham, "Cinderella or Bluebeard: The Double Plot of Evelina," L'Homme et La Nature / Man and Nature 5 (1986): 85-98, and in a monograph by Huang Mei, Transforming the Cinderella Dream: From Frances Burney to Charlotte Brontë (New Brunswick and London: Rutgers University Press, 1990). 
surprise," taking place in a setting "so entirely different from the usual sort." ${ }^{\prime 3}$ Not only the first scene but the entire act takes place at a milliner's shop in London in which Burney presents the everyday business of commercial exchange, evoking "the real world of making, buying, selling," even showing the actual "making of things" onstage (as Doody remarks), which is "a striking piece of stage naturalness for the period." ${ }^{44}$ The character of the milliner, Mrs. Wheedle, and her sharp business practices are realistically presented, as are the trio of milliner's assistants or apprentices, Miss Jenny, Miss Sally, and Miss Polly, who are assiduously learning the trade. Although the focus of the action settles on the gentry and their situation, the background of the shop, its owner, and her employees, is fleshed out with convincing authenticity. Millinery is a trade often used by Burney to contrast the world of self-indulgent luxuries enjoyed by the upper classes with the lot of the tradesmen who cater to their whims, a contrast which she uses to make a political point. ${ }^{45}$

There are other scenes set in the City by Burney; although she does not often name the streets, some would be recognizable to readers at the time. For instance, Cecilia's nightmare run begins after she alights from a coach she took from Fetter Lane; she then dashes madly through the streets until she collapses in a pawn shop. She was clearly in the financial district, very close to where Burney's mother once ran the "Golden Fan." Cecilia's collapse into a helpless state suggests a kind of reversion to childhood as a way out of her impossible situation, making the location (from Burney's point of view) even more apt. There are mentions of trade and milliners' shops, in particular, dotted throughout Burney's novels. When she first arrives in London, Evelina describes being taken to the dress shops and being "carried from one

43. Margaret Anne Doody, Frances Burney: The Life in the Works (New Brunswick: Rutgers University Press, 1988), 77.

44. Ibid., 77-80.

45. Catherine Gallagher makes the point that Burney herself was "raised to the trade" of writing, connecting gender to theories of literary and economic exchange in Nobody's Story: The Vanishing Acts of Women Writers in the Marketplace, 16701820 (Berkeley and Los Angeles: University of California Press, 1994), 215-17. Other works that connect Burney with the emerging literary-professional class are Betty Schellenberg, The Professionalization of Women Writers in Eighteenth-Century Britain (Cambridge: Cambridge University Press, 2005) and Cassandra Ulph, "Frances Burney's Private Professionalism," Journal for Eighteenth-Century Studies $3^{8.3}$ (2015): $377-93$. 
to another," probably along Cheapside where these shops were congregated. ${ }^{46}$ Camilla's troubles with debt begin with her dealings with the milliners who send her tasty trifles at an exorbitant cost. ${ }^{47}$ The fashion industry, its place in the economy and its social implications, was evidently situated on terrain that Burney knew well and had thought deeply about.

Burney's social and political messages come to fruition in The Wanderer (1814), that sprawling and most explicitly political and of her novels. ${ }^{48}$ In trying to bring out "FEMALE Difficulties," Burney cycles through various professions open to women, pointing out the incompatibility of the social code requiring feminine delicacy with the practical situations facing women, which require individual exertion. She shows how the modest behaviour demanded of women (which could be seen as a form of infantilization) sabotages all attempts to achieve financial independence or self-reliance. The theme is developed clearly within the novel through Elinor who is a passionate advocate for women's rights: she urges Juliet, "Put aside your prejudices, and forget that you are a dawdling woman, to remember that you are an active human being, and your FEMALE DIFFICULTIES will vanish into the vapour of which they are formed." ${ }^{49}$ The novel's theme is expressed not only in words but in actions, as Juliet cycles through various professions in search of self-dependence, and discovers new difficulties in each one. In Juliet's choice of professions, it seems as though Burney takes literally the adage "Write from what you know." First, she addresses the lot

46. Burney, Evelina, 27. The connection made by Burney between millinery and other forms of female labour that were "culturally invisible" is noted by Jennie Batchelor in Women's Work: Labour, Gender, Authorship, 1750-1830 (Manchester: Manchester University Press, 2010), 1-3. Chloe Wigston-Smith elaborates on the connection in Women, Work and Clothes in the Eighteenth-Century Novel (Cambridge: Cambridge University Press, 2013).

47. Henderson relates the ill-fated browsing of Camilla and Mrs. Mittin to developments in retail culture, in "Commerce and Masochistic Desire," as does Lynch in Economy of Character.

48. Recent critics who have discussed radicalism in The Wanderer are Andrea Austin, "Between Women: Frances Burney's The Wanderer," English Studies in Canada 22.3 (1996): 253-66; Christina Davidson, "Frances Burney, Elinor Joddrel, and the 'Defiance to All Forms' and 'Antique Prescriptions," The Burney Journal 12 (2012): 51-73; and Tara Ghoshal Wallace, "Rewriting Radicalism: Wollstonecraft in Burney's The Wanderer," Eighteenth-Century Fiction 24.3 (2012): 487-508.

49. Frances Burney, The Wanderer; or, Female Difficulties, ed. Margaret Anne Doody, Peter Sabor, and Robert L. Mack (Oxford: Oxford University Press, 1991), 318. 
of the musician, who "sings, perhaps, when he may be ready to cry," echoing the "drudge amid the smiles of Wealth \& Power" of Charles Burney, quoted above. She then moves through a series of occupations, all related to ladies' fashions (like the fan): from decorative sewing and embroidery, to millinery, to plain-sewing and dress-making. ${ }^{51}$ Burney also explores the different employment arrangements (full-time work, day-jobber, piece-worker, journey-woman) and the advantages or disadvantages of each. Her sympathetic and realistic representation of the life and conditions of the worker in the garment trade sounds a note of social protest that may gather added intensity and force from the grounds of personal experience. Erickson's discovery that Mary Kenn, an apprentice to a Cheapside haberdasher was "turned over" to Charles Burney's household in 1750, probably to work in his wife's fan shop, does not seem entirely irrelevant here. ${ }^{52}$

Having explored references to fashion and trade in Burney's novels, I should like to turn now to her journals and letters, in which it is even more possible to make a connection between the writing and the life. I shall be focusing particularly on mentions of fans in her private writing. Once alerted to the significance of the fan both as accoutrement of fashion and as symbol, it is remarkable how many times it occurs and in how many different guises. As a material object, the fan would have had particular significance for Burney; perhaps there was some old stock left at home inherited from her mother, or she may have received some as gifts from her grandmother, who was still involved in the trade, Erickson suggests, until Burney was at least fifteen and was alive until Burney was twenty-one. ${ }^{53}$ But even as a metaphor, the fan crops up repeatedly in Burney's journals, though its meaning and significance may vary and evolve with the passage of time.

In her youth, Burney seems particularly sensitized to gallantry that plays on the shape or image of the fan. The Early Journals contain two of these images; the first surviving references comes in a journal entry

50. Burney, Wanderer, 325 .

51. Andrea Henderson argues that the heroine herself is positioned as a commodity in "Burney's The Wanderer and Early Nineteenth-Century Commodity Fetishism," Nineteenth-Century Literature 57.1 (2002): 1-30.

52. Amy Louise Erickson, "Eleanor Mosley and Other Milliners in the City of London Companies 1700-1750," History Workshop Journal 71.1 (2011): 147-72, 153.

53. Erickson, "Esther Sleepe," 29-30. 
for [21] February 1770, which she writes soon after her first masquerade, still excited by the flattering attentions she was paid. In it, she records an acrostic written on her name which, she claims, is "very well worth pres[erving]." While dismissing the poem as "the most laughable stuff I ever saw," she proceeds, typically, to write it all down. The poem ends:

\author{
Beautiful, witty and young, \\ Unskilled in all deceits of Ton[gue,] \\ Reflecting glory on her sex, \\ None can her in Compliments perple[x;] \\ Easy in her manners as in her Dr[ess-] \\ You'll that this is Fanny all must gu[ess.]
}

"To complete the elegance \& bri[lliancy] of this Acrostick," she concludes, "the paper on which [it] is Wrote is cut out in the shape of a [Fan]." 54 The shape of the paper used by the clever admirer brings out the pun inherent in the short form of her name, "Fan," a nickname often used in the letters of Burney's father and other family members. After the éclat of her novels earned her invitations to the same evening assemblies to which her father had been invited, he liked to take "Fan in his hand" and attend them together. ${ }^{55}$

Another gallant compliment is paid to her using the metaphor of a fan although this time by an elderly admirer who is "galant to the Ladies to a most ridiculous degree." She writes, "He never comes without repeating some of his Verses - \& I can now recollect a stanza he has just told us - occasioned by some little flirtation with a Lady's Fan -":

No Wonder that this Fan should prove

A Vehicle to convey Love:

But to return it I desire,

Lest it too much should Fan the Fire.

The one verse of this man's tedious compliments which she finds worth recording was his clever play on the word "Fan." It would not be hard to suggest a motive for Burney's finding the verses so well "worth pre-

54. Early Journals and Letters, vol. 1, ed. Troide, 115-16; brackets in the original.

55. Hemlow, 465. She adapts a phrase used in a letter of Charles Burney of 6 November 1778 in which he describes a visit to Johnson: "I took Fan in my hand \& went to Bolt Court" (Letters of Charles Burney, ed. Ribeiro, 26o-61). 
serving" that she "flew out to write them down" (according to her own account). ${ }^{56}$

There are other mentions of fans in the Early Journals where they often form part of a stage costume and are associated with performance. A fan completes the costume of Burney's cross-dressing cousin James in the amateur theatricals at Worcester, ${ }^{57}$ presumably to signify femininity. A fan is also used to accessorize the dress of the wealthy and imposing widow Mrs. Walsingham whose fantastical costume and behaviour upon receiving Burney seemed like that of a character on stage. Burney writes the scene as though it were in a play: "She is rather deformed, \& ugly, though with a good profile;.... Her reception of me appeared rather singular; she was violently dressed,-a large Hoop, Flowers in her small \& full dressed cap, Ribbons \& ornaments extremely shewy, \& a Fan in her Hand." 58 A fan is used in some scenes to heighten the dramatic effect. Another intimidating introduction, this time to the redoubtable Mrs. Cholmondeley, also features a fan. Itching to engage with Burney (perhaps recognizing a kindred comic spirit), Mrs. Cholmondeley first taps her with her fan, and then begins "flirting" with it, as she hunts Burney "quite round the Card Table, from Chair to Chair," spouting "Ma fois" and speeches from her novels, and finally bursts out with her enthusiastic admiration. ${ }^{59}$ Though claiming to be abashed, Burney clearly enjoys the company of Cholmondeley (whose favourite character is, naturally enough, Mme. Duval), and who (Burney writes), is "very clever, very entertaining, \& very much unlike any body else." ${ }^{60}$ In this scene, the fan is used almost as a stage prop, to emphasize Cholmondeley's sportiveness and playful humour.

The fan is connected with flirtatiousness, though wielded this time by Burney, in her famous encounter with Richard Brinsley Sheridan which occurs not long afterwards. Here, the fan serves as a weapon of self-defence to hold his curiosity at bay while she retreats into a pose

56. Early Journals and Letters, vol. 1, ed. Troide, 223-24.

57. The Early Journals and Letters of Fanny Burney, vol. 2, ed. Lars Troide (Oxford: Oxford University Press; Montreal and Kingston, McGill-Queen's University Press, 1990), 247 .

58. Early Journals and Letters, vol. 5, ed. Troide and Cooke, 202-3.

59. Early Journals and Letters, vol. 3, ed. Troide and Cooke, 203-5, 215-19.

6o. Ibid., 227. 
of characteristic demureness to avoid telling inconvenient truths (i.e. having to admit that she is already writing a play, for fear of raising expectations). Sheridan, an actor as well as a theatre manager, is urging her to write a comedy for him to produce. In their witty and stage-like dialogue, Burney plays the role of reluctant ingénue, comparing herself explicitly to one of the Sheridan's characters (with metafictive reference), as though to draw attention to the artifice of their exchange:

[Sheridan asks:] But perhaps you have begun some thing? - may we ask? - Will you answer a Question candidly?'

F:B. - I don't know, - but as candidly as Mrs. Candour I think I certainly shall! $!^{61}$

Mr. Sheridan. What, then, are you about now?

F:B. - Why - twirling my Fan I think!'

Mr. Sheridan. No, no, - but what are you about at Home? - however,

- it is not a fair Question, so I won't press it.'

Yet he looked very inquisitive; but I was glad to get off without any downright answer. ${ }^{62}$

Always ill at ease when pressed about her writing, Burney avoids the question, looking down in embarrassment and focusing on her fan, latching onto it, it seems, as an anchor in these uneasy seas, though meanwhile remaining aware of her own gesture and performance.

The fans that figure in the Early Journals and Letters, written in Burney's youth, are associated with costumes, flirtation, dramatic gestures and theatrical performance. As Burney ages, and the exuberance of her journals fades, the fan, too, takes on more sombre colouring and significance. At court, where the extravagance of the dress means toil and trouble to Burney (both in managing her own and that of the Queen), the fan comes to symbolize different things: the routine of dressing and the tedium of her official duties, as Keeper of the Robes. It also serves as a mark of difference, to emphasize the ways in which Burney rebels or stands out.

A fan is always the finishing touch on the Queen's dress: the moment when Burney hands the fan and gloves marks the end of her

61. Mrs. Candour is an ironically named character in Sheridan's play, The School for Scandal (1777).

62. The encounter takes place on 6 January 1779 and is described in Early Journals and Letters, ed. Troide and Cooke, vol. 3, 234-5, emphasis in original. 
labours. ${ }^{63}$ But in some passages, Burney subverts this moment of completion, reversing the order in which she does things to encapsulate how unfitted she feels for her position, inattentive as she has always been to the niceties of fashion: "Tis fortunate for me I have not the handing them [the Queen's garments]!" she writes. "I should never know which to take first, embarrassed as I am, \& should run a prodigious risk of giving the Gown before the Hoop, \& the Fan before the Neck Handkerchief. ${ }^{64}$ Later, speaking candidly with a friend who, Burney writes, "told me, with a good deal of humour, that he suspected me of being rather absent in my official occupation, from little natural care about Toilettes, \& such things; I could not possibly deny this . . . 'I have even, I added,_\& not seldom!- handed her Her Fan before her Gown-\& her Gloves before her Cap!-but I am better in all that now!" 65 The ceremonial handing of the fan that marks the culmination of the ritual of dressing epitomizes the rigid routine imposed on her household by the Queen-against which Burney instinctively, at times, feels inclined to rebel.

In another scene, the fan is used to underline the extent to which Burney feels out of place in a world of privilege to which she does not belong. Here, the colour is at issue, with the lowliness of her position marked by the plainness of her fan. On 7 August 1786, on her third birthday, Princess Amelia is leading the royal family on the terrace, dressed very fine and carrying a "fan" (underlined) which, judging from Burney's emphasis, might be for the first time. Burney, who is not of rank to follow in their train, stands with Delany to watch the procession, when the King stops to speak to Delany and the Queen shows "a little surprise," to see Burney there. The Princess then:

slowly, of her own accord, came behind Mrs. Delany to look at me; . . . with her lips pouted out to kiss me.-I could not resist so innocent an invitation, but the moment I had accepted it, I was half afraid it seem, in so public a place, encouraging an improper liberty; however, there was no help for it. - She then took my Fan, \& having looked at it on both sides, gravely returned it me, saying " $\mathrm{O},-\mathrm{a}$ Brown Fan! ${ }^{66}$

63. See, for instance, Court Journals and Letters, vol. 1, ed. Sabor, 51.

64. Ibid., 34.

65. Court Journals and Letters, vol. 5, ed. Sill, 386, 226.

66. Court Journals and Letters, vol. 1, ed. Sabor, 81. 
In this scene, the plain brown fan that disappoints the little princess stands in for Burney, who is feeling ill at ease, anxious that she is somehow violating decorum, a fear that is fairly pervasive when she is at court, where (like Evelina) she constantly dreads committing some awkward faux pas. The pattern is repeated on another royal birthday when Amelia, perceiving Burney plainly dressed, loudly asks, “And won't Miss Burney be fine too?'-." ${ }^{67}$ With the innocent truth-telling of the child, Amelia's grave rejection of Burney's "Brown Fan" (which is closely linked with Burney's own identity) carries a deeper truth.

The ceremonial function of the fan is suggested when the Queen presents one to Burney in April 1789 to commemorate the King's recovery from "madness." 68 Burney also receives a fan as a gift from Hester Thrale's daughter who has "painted" it for Burney as a token of friendship. ${ }^{69}$ Fans appear elsewhere in the Court Journals: the Queen uses one to hide her emotion and disperse her tears after a near-fatal attack on the $\mathrm{King}^{70}$; Mme. La Roche uses one to convey her modest reluctance, when she pauses dramatically and "looks down at her fan" before undertaking to recount her romantic adventures (like a lady in a French romance). ${ }^{71}$ Burney herself uses one to hide her face at the theatre after being startled by a reference to Cecilia in the epilogue. ${ }^{72}$ The versatility of the fan is enacted sportively by Stephen Digby, imitating the affected gestures of a coquette. A suave courtier from a pedigreed family, Digby's intermittent attentions to Burney flatter her to dream, Cinderella-like, that he plans to rescue her from her intolerable position. At times, he visits her assiduously with a determined

67. Ibid., 186.

68. "The Queen graciously presented me with an extremely pretty Medal, of Green \& Gold, \& a motto Vive le Roi, upon the Thanksgiving occasion,-as well as a Fan, ornamented with the words Health restored to one, And Happiness to Millions. These I shall preserve while I live" (Court Journals and Letters, vol. 5, ed. Sill, 248).

69. Court Journals and Letters, vol. 3, ed. Clark, 189.

70. Court Journals and Letters, vol. 1, ed. Sabor, 113 .

71. Ibid., 171-2. The comparison to a heroine of French romances is made explicitly by Burney when she first meets La Roche: "I can suppose she has thought herself all her life the Model of the Favourite Heroine of her own Favourite Romance." That she finds her gestures self-dramatizing is indicated by her later somewhat acerbic comment, "I could scarcely believe I was not actually listening to a Clelia or a Cassandra recounting the Stories of her Youth" $(167,172)$.

72. The Court Journals and Letters of Frances Burney, vol. 2, ed. Stewart J. Cooke (Oxford: Clarendon, 2011), 193. 
intimacy, although she has already begun to question the sincerity of his intentions when, to stave off some awkwardness between them, he takes up her fan:

Finding I entered into nothing, he took up a Fan, which lay on my Table, \& began playing off various imitative airs with it,-exclaiming "how thoroughly useless a Toy!"

"No, I said, on the contrary, taken as an ornament, it was the most useful ornament of any belonging to full Dress; ocupying the Hands, giving the Eyes something to look at, \& taking away stiffness \& formality from the figure \& deportment."

"Men have no Fans, cried he; \& how do they do?"

"Worse!" quoth I, plumply.-

He laughed quite out, saying "That's ingenuous, however! - \& indeed, I must confess they are reduced, from time to time, to shift their Hands from one Pocket to another."

"Not to speak of lounging about in their Chairs, from one side to another! -"

"But the real use of a Fan, cried he, if there is any, is it not-to hide a particular blush, that ought not to appear?"

"O, no,-it would rather make it the sooner noticed."

"Not at all,-it may be done under pretence of absence-rubbing the Cheek, or more,-putting it up, accidentally, to the Eye-in a thousand ways."

He went through all these evolutions comically enough: \& then, putting aside his Toy, came back to graver matters, \& produced the Book he wished me to see. ${ }^{73}$

The extended discussion of the many functions of the fan, and Burney's praise of it as a "most useful ornament," is revealing, as are Digby's playful poses, in which he self-consciously flaunts the fan as an instrument whose purpose is to mask and to deceive. His actions may seem particularly apt to the reader, given the way his affair with Burney unravels, revealing his insincerity and duplicity. That the scene ends by contrasting his affected insouciance with his overt piety is particularly ironic.

I shall end with a poem by Burney, written almost at the midpoint of her time at court, in which, as Jocelyn Harris astutely notes, a fan is

73. Court Journals and Letters, vol. 5, ed. Sill, 104, 64 . 
used as "an avatar" to express Burney's own feelings of "wretchedness" and "imprisonment": ${ }^{7}$

The petition of a Fan

to its Mistress.

written during a long exile, and tedious imprisonment, in the drawer of a library table, April. 1788.

At the end, it is dated more precisely, 13 April 1788; significantly, it was written during the last illness of Mary Delany whose proximity and friendship had provided a crucial support to Burney at Windsor and who was then lying on her deathbed; her loss would only intensify Burney's sense of abandonment.

The poem begins with a plaintive address from the fan to its owner, appealing for release from the drawer: "my prison's hateful gloom" that seems to give voice to Burney's own feelings of confinement at court:

Take me, gentle Mistress, take me From my prison's hateful gloom:

Why, Oh! why so long forsake me?

Think how dreadful is my doom.

The fan then turns to retrospection, recalling fondly the life of beauty and fashion shared with its mistress, and stressing its sympathetic participation in the emotions of "the Fair":

Still on them have I attended:

Gently mew'd, when they were charm'd,

Rattled when they were offended,

Flutter'd, when they were alarm'd.

The fan presents itself as the ideal companion, stressing the empathetic role it played in concealing the "rising blush," associated with modesty, flirtation, and coquetry. The apostrophe to "Sympathy" which follows evokes the fellow-feeling considered the basis of social interaction, much prized by Digby as an essential ingredient to happiness:

Sympathy, dear source of pleasure,

These the boons thou canst extend:

74. Jocelyn Harris, Review of The Court Journals and Letters of Frances Burney, vols. 3 and 4, ed. Lorna J. Clark, Burney Letter 21.1 (2015): 12-14, 13. 
With them came a double treasure

In a mistress and a friend.

In the next five quatrains, the fan makes a strong appeal to remain with its mistress, recalling the many hours "Gaily" passed together when they were "united" - in "the Dance's motion . . . at Park or Play," or at the centre of a group of admiring "Belles and Beaux." Leaving the sociable past behind and turning to the present, the fan again describes the "dreary" situation in which it finds itself:

Hear, oh! hear my sad petition:

Scarce an human face I see:-

Think how dreary my condition,

Torn from all the world and thee.

The poem takes an interesting turn when the fan describes the place it has been found, in a library, amidst piles "of musty books and papers," which seems to evoke Charles Burney's study. The description suggests that the occasion of the poem may have been a visit paid by Burney to her home during which she found an old fan in a desk drawer, which evoked this train of reminiscence about the past and rumination on the present. At last, appealing once more for the restoration of its liberty, the fan repeats the opening stanza.

In this poem, through the clever device of the fan, Burney gives voice to her own feelings of being exiled and imprisoned at court; she expresses regret for the loss of her social life with friends and family and her yearning for release. The plaintive cry of the fan lamenting its plight resembles some of the passages in Burney's Court Journals in which she deplores the intellectual solitude of her position. ${ }^{75}$ It seems particularly fitting that in this poem Burney would embody her own identity in that of the fan, talisman of the lost mother, and project onto it her feelings of loneliness, abandonment, and desertion.

A fan rarely if ever makes an appearance in Burney's journals after her retirement from court in July 1791, and significantly, the one time she mentions it as part of her own attire is when she is again performing her former duties, filling in temporarily as dresser to the Queen. A final coda on the role of the fan at court comes in a scene described in her journals almost a year after her resignation: at a public breakfast,

75. Court Journals and Letters, vol. 2, ed. Cooke, 24-25. 
Burney once again encounters one of her irksome colleagues, Mme. LaFite, who had often embarrassed Burney with her pressing attentions, assumption of intimacy, and histrionic self-display. At the unexpected encounter, Burney puts out her hand which LaFite seizes, and keeps "close grasped between both her own, (though her Fan nipt one of my fingers till I was ready to make Faces,) with a most resolute empressement." ${ }^{\prime 6}$ This image of Burney, wounded and imprisoned by the fan wielded by her colleague, while unable to escape, seems a fitting encapsulation of her experience in the Queen's household and the attitude she retained to her fellow inmates there.

In conclusion, Erickson's exploration of the discovery of her mother's Cheapside fan shop (deeply embedded in Burney's psyche) has important implications for those issues of class, gender and money that pervade Burney's writing, the ramifications of which have only begun to be unpacked. It is illuminating to trace the uses and significance of the fan (and other elements of high fashion) both as material object and as symbol in Burney's public and private writing in light of this discovery. The fan's connection to the exuberance of the Early Journals fades in the Court Journals where it acquires more complexity as Burney matures, and comes to symbolize the joys and freedom of youth that have been lost to her at court. Fans are rarely mentioned in the later journals, as Burney moves into marriage, motherhood and middle age: her life becomes quieter, and her dress simpler and more functional; coincidentally, the journal accounts also begin to lose some of their self-conscious dramatic qualities. In Burney's novels and plays, the role played by the milliner's shop is an important one, as the site where rich and poor encounter; it heightens the contrast and serves as a useful vehicle for her social and political messages. Above all, the importance of the fan as material object and as symbol demonstrates the use that Burney makes of the elements of her environment, and how she transforms them in her writing. The sign of "the Golden Fan and Seven Stars" under which her mother traded could be seen as a mark of shame or embarrassment, but instead it becomes a source of inspiration and imagery whose potential is richly exploited.

76. Journals and Letters, vol. 1, ed. Hemlow, 165. 